\title{
Kecenderungan Perilaku Narsistik pada Calon Legislatif
}

\author{
Ernida Marietha Manurung*
}

Program Studi Psikologi, Fakultas Farmasi dan Kesehatan Institut Kesehatan Helvetia, Indonesia

Diterima: April 2019; Disetujui: April 2019; Dipublish: April 2019

*E-mail: ernida.2010@gmail.com

\begin{abstract}
Abstrak
Penelitian ini bertujuan untuk mengetahui beberapa karakteristik dari kecenderungan perilaku narsistik secara klinis maupun sosial pada calon legislatif selama berkampanye melakukan sosialisasi. Penelitian ini menggunakan pendekatan kualitatif. Responden penelitian ini sebanyak dua orang yang ikut mencalonkan diri sebagai calon legislatif di Pemilu Legislatif 9 April 2009. Metode pengumpulan data yang digunakan dalam penelitian ini adalah dengan menggunakan metode wawancara mendalam dan observasi. Hasil penelitian ini menunjukkan bahwa kecenderungan perilaku narsistik pada calon legislatif merupakan bagian dari gangguan kepribadian narsistik. Gangguan kepribadian narsistik ini dapat dilihat dari self esteem dan interpersonal trust yang terlalu tinggi dalam menarik simpati masyarakat. Hal ini terlihat dari cara kedua responden dalam bersosialisasi yang selalu menceritakan mengenai pengabdian-pengabdian mereka yang selama ini dilakukan dan sikap optimis mereka dalam menarik simpati masyarakat dengan memberikan sumbangan-sumbangan sosial dan aktif dalam beberapa kegiatan. Berdasarkan usaha yang telah dilakukan, mereka percaya bahwa keluarga, teman dekat dan masyarakat akan memilih mereka di Pemilu 9 April 2009.
\end{abstract}

\section{Kata Kunci: Kecenderungan Perilaku Narsistik, Gangguan Kepribadian Narsistik}

\begin{abstract}
This research intended to find out the narsistic tendency behavior on the legislative candidates, clinically and socially, during the campaign or doing the socialization. This research was used qualitative approach. This research used two respondents who nominated themselves as the legislative candidates in the Legislative Election in $9^{\text {th }}$ of April 2009. The collecting data method used was indepth interview and observation. The result of this research showed that narsistic indication behavior of legislative candidates was a part of narsistic personality disorder. This narsistic behavior disorder could be seen from the over self-esteem and interpersonal trust in getting the society interests. This was seen from the ways of the two respondents in socializing their programs were always telling others about their performances, their dedications and their optimistic behavior to get society symphaty by giving social contribution and being active in some activities. Based on the efforts that had been done, they believed that their family, close friends and the society would choose them in the election in $9^{\text {th }}$ of April 2009.
\end{abstract}

Keyword: Tendency of Narcissism, Narcisstic Personality Disorder

How to Cite: Manurung. E.M (2019). Kecenderungan Perilaku Narsistik Pada Calon Legislatif. Journal of Education, Humaniora and Social Sciences (JEHSS). 1 (3): 196-201.

\section{PENDAHULUAN}

Istilah Negara Kesatuan Republik Indonesia (NKRI) merupakan Negara dimana sistem pemerintahannya menganut sistem pemerintahan demokrasi. Kata "Demokrasi" berasal dari dua kata, yaitu demos yang berarti rakyat dan krotos/cratein yang berarti pemerintahan. Maka dapat diartikan sebagai pemerintahan rakyat, atau yang lebih dikenal sebagai pemerintahan dari 感 http://mahesainstitute.web.id/ojs2/index.php/jehss

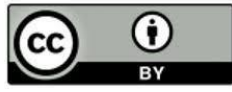


rakyat, oleh rakyat dan untuk rakyat (http://massofa.wordpress.com). Demokrasi berkembang menjadi sebuah bentuk atau mekanisme sistem pemerintahan suatu Negara sebagai upaya mewujudkan kedaulatan rakyat (kekuasaan warga negara) atas Negara untuk dijalankan oleh pemerintahan negara tersebut. Salah satu pilar demokrasi adalah prinsip trias politicca yang membagi ketiga kekuasaan politik negara (Eksekutif, Yudikatif dan Legislatif) untuk mewujudkan dalam tiga jenis lembaga negara yang saling lepas (independen) dan berusaha dalam peringkat yang sejajar satu sama lain. Kesejajaran dan independensi ketiga jenis lembaga negara ini diperlukan agara ketiga lembaga ini dapat saling mengawasi dan mengontrol berdasarkan prinsip check and balance.

Dalam rangka menjalankan sistem Pemerintahan Demokrasi di Indonesia maka diadakan pemilihan umum (Pemilu) untuk memilih wakil rakyat sebagai anggota-anggota lembaga melalui pemilihan umum yang pada akhirnya terpilih sebagai perangkat aparatur negara yang bertanggung jawab dalam melaksanakan tugasnya. Menurut Gunawan (2008) Prinsip-psinsip dalam pemilu merupakan salah satu syarat atau ciri dari negara demokrasi, suatu cara atau sarana untuk memilih wakil rakyat yang akan duduk dalam Badan Perwakilan Rakyat dan reliasi hak asasi politik dan sarana untuk melaksanakan kedaulatan rakyat. Pesta demokrasi dibuka dengan pemilihan secara umum calon-calon legislatif atau sering disebut dengan "caleg" sebagai wakil rakyat di pemerintahan (Kadir, 2013).

Tepat pada hari Kamis, 9 April 2009 Indonesia mengadakan pemilihan umum untuk calon legislatif. Pada sistem demokrasi dalam pemilu ini memberikan kesempatan pada setiap orang atau organisasi mendaftarkan partai dan calon legislatif yang akan dicalonkan. Berdasarkan informasi yang telah ditetapkan oleh Komisi Pemilihan Umum (KPU) ada 44 partai pesera pemilu. Pencalonan ke-44 parpol dan ribuan peserta calon legislatif yang terdiri atas sebanyak 11.215 orang memperebutkan 560 kursi DPR dan 1.109 orang bersaing mendapatkan 132 kursi DPD. Sekitar 112.000 orang bersaing mendapatkan 1.998 kursi di DPRD provinsi dan 1,5 juta orang bersaing merebut 15.750 kursi DPRD Kbupaten/Kota membuat masyarakat semakin bingung untuk menentukan yang terbaik sebagai pilihannya di pemilu 9 April 2009 (http://www.sinarharapan.co.id/berita/0903/25/kesra01.html).

Selama berkampanye terlihat partai politik maupun calon legislatif yang mereka usung berusaha mengeksploitasi dirinya dengan memajang atribut-atribut partai dan calon legislatif pada tiap sisi jalan, memasang iklan di media cetak atau elektronik secara berlebihan dan menggerakkan tim suksesnya untuk membantu sosialisasi ke tempat-tempat yang mereka tuju. Minauli (2009) dalam seminar nasional psikologi politik menyatakan banyak calon legislatif teridentifikasi kecenderungan narsistik. Narsistik merupakan gangguan kepribadian dimana individu merasa dirinya sebagai orang penting dan dikagumi oleh banyak orang, dan hal ini sebagai bagian kebutuhannya (Kaplan \& Sadock, 1997).

Selanjutnya Gunderson, Ronningstam dan Smith (dalam Barlow\&Durand, 2007) menyatakan orang dengan Narcissistic Personality Disorder merasa dirinya sangat penting namun hal tersebut sangat tidak beralasan dan sangat memperhatikan diri mereka sendiri sehingga mereka memiliki tingkat sensitivitas dan kepedulian yang rendah terhadap orang lain. Hal ini terlihat dari perilaku-perilaku calon legislatif dalam berkampanye atau sosialisasi. Mereka menarik simpati masyarakat dengan mengumbar prestasi kerja dan janji-janji manis lainnya. Mereka tidak hanya membutuhkan pemujuaan dari partisipan namun juga keinginan yang besar untuk berhasil.

Diketahui bahwa self-esteem orang yang narsis mengalami inflasi dan hal tersebut diasosiasikan dengan perasaan sebagai pihak superior dan perasaan dapat memberikan yang terbaik pada orang lain. Selain itu dengan dana yang besar calon legislatif menginstruksikan tim suksesnya untuk membagikan kaos, topi, dan kartu nama kepada partisipan yang pendukung. Mereka memiliki harapan besar dapat mengantongi suara pastisipan dalam pemilihan nanti. Perilaku-perilaku tersebut cukup memenuhi beberapa kriteria perilaku narsistik dalam Diagnostic and Statistical Manual of Mental Disoerder edisi keempat (dalam APA, 2000).

Kegiatan lainnya juga seperti memperbaiki beberapa ruas jalan, memberikan bantuan pada sekelompok orang atau persatuan marga serta biaya-biaya lainnya menunjukkan sikap 
mendominasi suara partisipan untuk tidak beralih kepada calon legislatif lain. Mereka mencoba menarik semua simpati dengan usaha-usaha yang dapat dikembangkan. Setiap calon legislatif tampaknya tidak mau kalah dengan caleg-caleg lainnya yang juga ikut bersaing dalam pemilihan umum sehingga kadang kala menjatuhkan profile dari calon legislatif lainnya.

Pada kehidupan sosial, kecenderungan perilaku narsistik diidentifikasikan dengan sikap yang berlebihan dalam menilai dirinya dan mengenai orang lain (interpersonal trust). Sifat berlebihan ini membawa diri hingga merusak ikatan sosial dan mendistorsi sikap terhadap masa depan terkait pada estimasi (http://www.epsikologi.com/epsi/klinis_detail.asp?id=497). Istilah kepercayaan interpersonal (insterpersonal trust) sebagai gambaran yang positif mengenai orang lain mengakibatkan harapan yang positif mengenai intense dan motif orang asing. Sebaliknya gambaran mengenai orang lain yang negatif mengenai apa yang diiginkan dan dimaui oleh orang asing disebut ketidakpercayaan (mistrust). Sikap diatas dapat kita lihat dari perilaku beberapa calon legislatif di lapangan.

Mereka mencoba memenuhi keinginan-keinginan tersebut dengan mengganggap dirinya lebih hebat dari orang lain dan merasa mereka adalah satu-satunya yang terhebat. Hubungan interpersonal mereka tidak berlangsung baik sebab mereka sangat bergantung pada pujianpujian dari orang lain yang selalu mereka cari dan kadang kala menunjukkan perasaan iri dan sombong. Setiap calon legislatif memiliki kebutuhan yang besar untuk menang. Berbagai cara dan usaha dilakukan meskipun harus menghabiskan biaya yang besar untuk membuat mereka menang dalam pemilu. Kemenangan yang diraih sebagai anggota legislatif dalam pemilu merupakan suatu kebanggaan yang besar.

Pada sisi lainnya seseorang yang menunjukkan perilaku narsistik cenderung mengalami kecemasan dan perasaan tidak aman yang rendah. Hal ini sejalan dengan perasaan khawatir dan stres yang dikemukakan kedua responden. Persoalan tersebut terjadi apabila mereka mengetahui partisipan mereka beralih ke calon legislatif lainnya. Pada beberapa informasi yang ada diketahui seorang calon legislatif menjadi stres, depresi hingga melakukan tindakan bunuh diri ketika mengetahui kekalahannya dalam pemilihan calon legislatif. Persoalan tersebut menunjukkan adanya pengaruh self esteem yang mengalami inflasi, begitu juga dengan interpersonal trust calon legislatif terhadap lingkungan.

Dalam mengantisipasi resiko dari kekalahan pemilihan calon legislatif, seorang calon legislatif harus dapat melakukan coping untuk menghindari perilaku menyimpang yang memungkinkan untuk terjadi. Lazarus dan Folkman (dalam Sarafino, 1990) menyatakan pengertian coping adalah suatu proses dimana individu mencoba untuk mengelola jarak yang ada antara tuntutan-tuntutan dengan sumber-sumber daya yang mereka gunakan dalam menghadapi situasi stressfull. Individu akan memberikan reaksi yang berbeda untuk mengatasi stres. Secara umum stres dapat diatasi dengan melakukan transaksi dengan lingkungan dimana hubungan transaksi ini merupakan suatu proses yang dinamis. Strategi coping merupakan situasi stres yang menekan dengan melakukan perubahan kognitif maupun perilaku guna memperoleh rasa aman dalam dirinya.

\section{METODE PENELITIAN}

Metode kualitatif berusaha memahami suatu gejala sebagaimana pemahaman responden yang diteliti, dengan penekanan pada aspek subjektif dari perilaku seseorang (Poerwandari, 2009). Selanjutnya Taylor dan Bogdan (1998) menyatakan bahwa penelitian kualitatif memberikan kesempatan pada peneliti untuk memahami cara responden menggambarkan dunia sekitarnya berdasarkan cara pola berfikir mereka. Peneliti berusaha masuk ke dunia konseptual subjek yang diteliti untuk menangkap apa dan bagaimana sesuatu terjadi. Merujuk pada masalah yang hendak dijawab maka penelitian ini menggunakan pendekatan kualitatif yang dipandang dapat mengetahui lebih jelas bagaimana kecenderungan perilaku narsistik pada calon legislatif dengan cara deskriptif. 
Penelitian ini menggunakan metode pengambilan data dengan melakukan wawancara mendalam (indepth interview). Hal ini bertujuan untuk memperoleh gambaran yang lebih luas dan mendalam tentang kecenderungan perilaku narsistik pada calon legislatif. Selanjutnya penelitian ini dibantu dengan metode observasi. Wawancara dilengkapi dengan pedoman wawancara tanpa menentukan urutan pertanyaan saat dilakukannya penelitian. Sementara observasi dilakukan dengan mengamati langsung aktivitas responden dengan menggunakan catatan lapangan dan pengambilan foto tertentu saat kegiatan kampanye atau sosialisasi. Dalam hal ini intonasi suara, keadaan emosi dan interaksi responden dengan lingkungannya turut diobservasi.

Responden dalam penelitian ini berjumlah dua orang. Poerwandari (1998) menyatakan bahwa tidak terdapat aturan yang pasti mengenai jumlah responden. Tergantung kepada apa yang ingin diketahui, tujuan serta manfaat penelitian. Kriteria responden yaitu terdaftar dalam partai politik dan juga terdaftar sebagai calon legislatif yang sah dan aktif. Penelitian ini dilakukan di Kabupaten Asahan Kota Kisaran.

\section{HASIL DAN PEMBAHASAN}

Hasil dan pembahasan dalam penelitian ini menunjukkan masing-masing responden memiliki kecenderungan perilaku narsistik dan memenuhi sebagian dari kriteria perilaku narsistik dalam DSM IV-TR (APA, 2000). Hal ini dijelaskan dalam hasil analisis intrapersonal kedua responden yang mengungkapkan bagaimana perilaku-perilaku yang ditunjukkan masingmasing responden ketika menyampaikan visi dan misi kedua responden sebagai calon legislatif. Selain itu usaha dan cara yang dilakukan selama melakukan kampanye ataupun sosialisasi selama 8-9 bulan.

Pada hasil analisis intrapersonal responden I (Bapak Tigor). Kecenderungan perilaku narsistik tampak dari visi dan misi yang ia kembangkan dengan adanya dorongan untuk membebaskan rakyat dari belenggu penderitaan dengan harapan apabila nantinya terpilih dan duduk menjadi anggota legislatif. Bapak Tigor ingin menunjukkan rasa kepeduliannya kepada golongan masyarakat kecil yaitu melalui peningkatan taraf kehidupan masyarakat dan memperjuangkan aspirasi masyarakat. Dalam hal ini Bapak Tigor memiliki perasaan grandiositas bahwa dirinya memiliki talenta yang luar biasa untuk dapat membebaskan rakyat dari belenggu penderitaan. Usaha-usaha untuk meningkatkan taraf kehidupan masyarakat ia kemukakan dengan program kerja kedepan. Menurut Bapak Tigor dengan pengalamannya sebagai seorang kepala lingkungan membuktikan masih banyak masyarakat dalam kekurangan. Tingkat self esteem juga semakin kuat dimana sebagai kepala lingkungan ia tanggap dan melayani persoalanpersoalan di lingkungannya.

Dalam usaha dan cara kerjanya selama berkampanye dan juga sosialisasi sangat meningkatkan rasa percaya diri yang tinggi untuk dipilih. Bapak Tigor mengatakan dengan sosialisasi yang lancar, baik di lingkungan gereja, perkumpulan marga dan temat-tempat lainnya ia sudah dapat menarik simpati jemaat gereja dan keluarga besar perkumpulan marga yang ia datangi. Riwayat hubungan yang baik, komunikasi yang baik dan keterbukaan orang-orang yang mendukungnya membuatnya berpikir positif kalau doa dan dukungan kepadanya banyak ia terima. Ia memiliki interpersonal trust yang besar terhadap lingkungan yang siap memilihnya. Bapak Tigor percaya dengan sikap dan tanggung jawabnya sebagai pelayan gereja selama ini akan banyak jemaat yang akan membantunya. Ia juga menitipkan kartu nama dan berpesan dengan kerendahan hati untuk dibantu mengajak sanak saudara memilih Bapak Tigor di Pemilu 2009.

Adapun usaha lainnya yang dilakukan untuk menarik simpati masyarakat yaitu dengan pemasangan baleho, membagikan kartu nama dan kalender, spanduk, mancis dan kipas tangan yang berfotokan Bapak Tigor dan memberikan bantuan ataupun dana yang Bapak Tigor yakini dapat mengantongi suara masyarakat. Ia mengeksploitasi orang lain untuk mencapai tujuannya dengan menggerakkan beberapa tim sukses yang ia yakini bekerja keras untuk memenangkan Bapak Tigor di pemilihan ini. Ia sangat puas dengan cara kerja tim suksesnya. Hal ini tampak dari kegiatan sosialisasi yang lancar dan adanya penerimaan yang baik dari partisipan yang datang. Ia 
berpikir bahwa usaha yang dilakukannya sudah sangat maksimal dan mampu bersaing dengan calon legislatif lainnya. Meskipun dalam masa kampanye ini ada tim suksesnya keluar namun hal ini tidak menghambatnya untuk menggerakkan tim sukses lainnya.

Pada hasil analisis intrapersonal responden II (bapak Aris). Kecenderungan perilaku narsistik juga sama tampaknya dengan Bapak Tigor. Pencalonan kembali untuk periode kedua membuat Bapak Aris semakin percaya diri dalam mengembangkan visi dan misi yang dimilikinya. Ia menyatakan kalau visi dan misinya sudah ia tunjukkan ketika ia menjabat sebagai anggota dewan selama lima tahun. Ia bertanggung jawab dalam perannya sebagai wakil rakyat dimana kesejahteraan yang telah ia lakukan adalah dengan membangun beberapa jalan yang rusak sebagai persoalan-persoalan di kota Kisaran ini. Ia percaya banyak orang yang siap mendukung visi dan misi yang ia miliki.

Bapak Aris mengatakan bahwa sangat penting melakukan pendekatan kepada masyarakat. Untuk itu dalam kampanye dan sosialisasi ia harus percaya diri memperkenalkan diri dan tujuannya dalam melakukan kegiatan ini. Selama menjalankan sosialisasi, ia kerap membuktikan bahwa dirinya seorang wakil rakyat yang bertanggung jawab atas perannya. Ia juga mengatakan aktif dan berperan ketika acara-acara dan kegiatan kerohanian. Ia siap membantu hal-hal yang diperlukan. Dengan rasa percaya diri yang ia miliki ia menjelaskan hal-hal yang telah ia lakukan dan memohon doa dan dukungannya untuk membantu Bapak Aris menang kembali sebagai calon legislatif. Ia menggambarkan dirinya begitu penting dan sangat diharapkan daripada orang lain. Selain itu self esteem yang dimilikinya menunjukkan adanya perilaku mengeksploitasi dirinya untuk kepentingan pribadinya.

Usaha lain yang ia lakukan adalah dengan menggerakkan lebih banyak tim sukses dan relawan untuk memenangkannya kembali sebagai anggota dewan. Perilaku eksploitasi diri yang ia lakukan adalah dengan memasang baleho dan spanduk pada sisi jalan. Selain itu penyebaran kartu nama dan memberikan dana-dana bantuan pada beberpa kegaitan baik kegiatan perkumpulan marga, adat, kerohanian yang ia yakini dapat mengantongi lebih banyak suara partisipan. Pada responden kedua ini, interpersonal trust sudah terbentuk kuat dimana penilaian Bapak Aris terhadap lingkungannya yang siap mendukungnya dalam pencalonan di pemilu ini. Hal ini ia tambahkan dengan kedekatannya kepada masyarakat, perkumpulan marga, gereja dan pemuda pemudi setempat.

Berdasarkan hasil analisis interpersonal responden I dan II menunjukkan beberapa kriteria kecenderungan perilaku narsistik yang dikemukakan dalam DSM-IV-TR (APA, 2000) seperti adanya perasaan grandiositas bahwa dirinya orang yang penting seperti halnya memiliki talenta yang luar biasa. Pada kedua responden tampak menunjukkan kebolehannya untuk menampung semua aspirasi masyarakan dalam persoalan-persoalan yang ada. Kemampuan lainnya yaitu membebaskan rakyat dari belenggu penderitaan dengan usaha-usaha untuk meningkatkan taraf kehidupan masyarakat dengan program kerja yang dimiliki. Hal ini disampaikan lewat visi dan misi selama melakukan kegiatan kampanye dan sosialisasi. Tujuan visi dan misi ini yaitu untuk mendapatkan simpati dan pujian kalau kedua responden memiliki tekad dan kemampuan sebagai wakil rakyat.

Selanjutnya Baron dan Byrne (2003) menjelaskan perilaku narsistik dalam ranah sosial dengan memperhatikan self esteem dan interpersonal trust yang dimiliki oleh kedua responden. Dari hasil analisis interpersonal ini didapatkan kedua responden memilki self esteem yang tinggi dalam mencari kesuksesan dan kekuasaan di pemilihan umum 2009 ini. Kedua responden tampak mengekspresikan diri dengan baik, bagaimana kedua responden dapat dipercaya lewat program-program kerja yang dimilikinya. Selain itu membuktikan kalau kedua responden sebagai calon legislatif memiliki kedekatan dan berhasil menciptakan hubungan sosial yang baik. Kedua responden percaya dengan kualitas diri yang mereka miliki dapat menarik simpati masyarakat dan mengantongi suara yang mereka butuhkan. Dengan sosialisasi yang berjalan dengan lancar dan masyarakat yang menerima kehadiran kedua responden menjadi sebuah dasar penilaian positif kedua responden memiliki perasaan berharga dan patut dipilih. 
Kedua responden juga mengeksploitasi diri. Hal ini dilakukan dengan mengerahkan tenaga tim sukses yang mereka miliki. Tujuannya adalah membantu kedua responden untuk lebih cepat dikenal oleh masyarakat setempat. Kegiatan dilakukan dengan memasang baleho dan spanduk pada sisi-sisi jalan, menyebarkan kartu nama diberbagai acara. Selain itu megikuti undanganundangan dari masyarakat ataupun mendatangi acara-acara yang diselenggarakan seperti kegiatan rohani, kegiatan perkumpulan marga dan hal lainnya. Kedua responden juga memberikan bantuan dana sebagai rasa keikutsertaan kedua responden dalam acara tersebut. Dengan cara tersebut kedua responden semakin mudah mendominasi beberapa aspek yang mereka percaya akan memberikan dukungan kepada kedua responden sebagai calon legislatif.

\section{SIMPULAN}

Kedua responden yang mengikuti pencalonan di pemilu legislatif 2009 sangat optimis dalam menunjukkan visi dan misi mereka kepada masyarakat dengan tujuan agar masyarakat khusunya partisipan yang mereka harapkan dapat memilih mereka. Adanya sikap yang berlebihan dalam menceritakan usaha dan keberhasilan kedua responden dalam memberikan pelayanan kepada masyarakat baik sebagai kepala lingkungan ataupun juga sebagai wakil rakyat selama lima tahun. Kedua responden self esteem yang tinggi bagaimana mereka menempatkan dirinya menjadi berharga dan patut untuk dipilih. Mereka juga mencoba mendominasi masyarakat dengan kegiatan kampanye dan sosialisasi sebagai program kerja mereka sebelum pemilihan umum. Kecenderungan perilaku narsistik yang ditunjukkan pasangan calon legislatif juga turut menumbuhkan interpersonal trust kedua responden kepada masyarakat, keluarga, teman dekat dan aspek-aspek lainnya yang selama ini telah terjalin hubungan komunikasi dan sosial yang baik.

\section{DAFTAR PUSTAKA}

Alloy, L.A dan John H. (2003). Abnormal Psychology (current perspective). Ninth Edition. Thomson Wadsworth.

American Psychiartic Association. Diagnostic and Statistical Manual of Mental Disorder. $4^{\text {th }}$ Ed., text revised. Washington, DC: American Psychiatric Press, Inc.2000.

Baderu, C. (2007). Sejarah Partai Politik. http://bluefame.com/lofiversion/index.php/tl50055.html. Tanggal Akes 28 Maret 2009

Barlow, D.H. dan Durand, V.M. (2007). Intisari Psikologi Abnormal, Edisi keempat. Yogyakarta. Penerbit Pustaka Belajar.

Baron, R.A. \& Donn, B. (2003). Psikologi Sosial. Edisi ke 10, Jilid 1. Jakrta: Erlangga.

Baron, R.A. \& Donn. B. (2003). Psikologi Sosial. Edisi ke 10, Jilid 2. Jakrta: Erlangga.

Endrawan, S. (2009). Caleg Terlalu Percaya Diri Untuk Menang.http://www.ilmupsikologi.com/?=419. Tanggal akses 28 Maret 2009

Goleman. (2009). Perilaku Berlebihan di Kalangan Elit Politik.http://massofa.wordpress.com/2009/02/02/perilaku-berlebihan-di-kalangan-politikus/. Tanggal akses 1 Februari 2009.

Gunawan, M. (2008). Buku Pintar Calon Legislatif (DPRD, DPRD \& DPD). Jakarta: Visimedia.

Kadir, A., (2013). Peranan Partai Politik dalam Menanggulangi Golongan Putih (Golput) pada Pemilihan Legislatif 2009, Jurnal Ilmu Pemerintahan dan Sosial Politik, 1 (1): 65-75

Kaplan dan Sadock. (1997). Sinopsis Psikiatri; Ilmu Pengetahuan Psikiatri Klinis. Edisi ke 7, Jilid 2. Jakarta: Binarupa Aksara.

Minauli, I. (2006). Metode Observasi. Medan: USU Perss.

Nevid dan Speencer. (2005). Psikologi Abnormal, Edisi kelima. Jakarta: Erlangga.

Poerwandari, E.K. (2007). Pendekatan Kualitatif Untuk Penelitian Perilaku Manusia. Jakarta: Perfecta Universitas Indonesia.

Sutanto, L. (2007). Corak Narsisme. http://www.isodoruslilijawablogspot.com/2008/04/pilkada-dannarsisme-elite.html. Tanggal akses 03 April 2008

$\begin{array}{lllll}\text { Teti, } & \text { N.S. } & \text { (2004). } & \text { Karakteristik Individu Self- }\end{array}$ EsteemTinggi.http://bustanova.wordpress.com/2008/11/07/self-esteem-dannarcissisticpersonality-disoorder. Tanggal akses 04 April 2009.

Tim Redaksi Fokusmedia. (2008). Undang-Undang Partai Politik, Bandung: Fokusmedia.

Tim Redaksi Fokusmedia. (2008). Undang-Undang Pemilu DPR, DPD \& DPRD. Jakarta: CV. Karya Gemilang. 
